\title{
Immunobiological activities of chemically defined lipid A from lipopolysaccharides of Porphyromonas gingivalis
}

\author{
Tomohiko Ogawa, Hiroshi Uchida and Kayoko Amino
}

Author for correspondence: Tomohiko Ogawa. Tel: +8168765711.

Department of Oral

Microbiology, Faculty of Dentistry Osaka University, Suita-Osaka, 565 Japan

\begin{abstract}
Immunobiological activities of chemically defined lipid A from lipopolysaccharides (LPS) of Porphyromonas gingivalis strain 381, which possesses $\beta-(1 \rightarrow 6)$-linked glucosamine disaccharide 1-monophosphate, with 3hydroxy-15-methylhexadecanoyl and 3-hexadecanoyloxy-15methylhexadecanoyl groups at the 2- and 2'-positions, respectively, were compared with those of synthetic Escherichia coli-type lipid A (compound 506) and Salmonella-type lipid A (compound 516). P. gingivalis lipid A and its LPS induced stronger or comparable production of the cytokines interleukin-1 receptor antagonist (IL-1ra), IL-6, IL-8, granulocyte-macrophage colonystimulating factor and interferon- $\gamma$ as compared with compounds 506 and 516 in the culture supernatants of human peripheral blood monocytes or mononuclear cells. However, the $P$. gingivalis preparations showed low activity in inducing the production of IL-1 $\beta$ and tumour necrosis factor- $\alpha$. Clear antagonistic effects of $P$. gingivalis lipid $A$ and its LPS against IL-1 $\beta$ production induced by $E$. coli LPS or compound 506 were seen. Furthermore, P. gingivalis lipid $A$ and its LPS had marked immunopharmacological activities, i.e. antitumour, natural killer cell and antiviral activities. Its monophosphorylation pattern and the presence and position of fatty acids possessing acyl chains of considerable length are unique to $P$. gingivalis lipid $A$, differing from enterobacterial lipid As. Its good balance between agonistic and antagonistic effects, making it a possible candidate for use as an immunomodulatory drug, may be attributable to these unique features.
\end{abstract}

Keywords: Porphyromonas gingivalis, lipopolysaccharide, lipid A, cytokine induction, immunopharmacological activity

\section{INTRODUCTION}

Lipopolysaccharides (LPS) are a major component of the outer membrane of Gram-negative bacteria. LPS stimulate the host cells in experimental animals and humans, and have a variety of pathophysiological effects (Morrison \& Ryan, 1979). Among the host cells, the mononuclear phagocytes are important as primary targets of LPS. The LPS-stimulated monocytes/macrophages produce proinflammatory and anti-inflammatory cytokines, which

Abbreviations: FBS, foetal bovine serum; GM-CSF, granulocytemacrophage colony-stimulating factor; IFN- $\gamma$, interferon- $\gamma$; IL-1, interleukin-1; IL-1 ra, interleukin-1 receptor antagonist; IL-6, interleukin-6; IL-8, interleukin-8; NK, natural killer; PBMC, peripheral blood mononuclear cells; $\mathrm{TCID}_{504} 50 \%$ tissue culture infective dose; TNF- $\alpha$, tumour necrosis factor. play an important role in mediating the endotoxic and beneficial effects of endotoxin (Vogel \& Hogan, 1990).

Lipid A is generally regarded as the endotoxic principle and bioactive centre of LPS. The generalized structure of the lipid A component, which represents the lipophilic portion of LPS, consists of a $\beta$ - $(1 \rightarrow 6)$-linked disaccharide which carries a glycosidic and a nonglycosidic phosphoryl group, and ( $R$ )-3-hydroxy fatty acids in ester and amide linkage, some of which are acylated at their 3-hydroxyl group. The lipid A structures corresponding to preparations of Escherichia coli-, Salmonella- and other enterobacterial-type lipid As have been chemically defined and synthesized (Takayama \& Qureshi, 1992; Kusumoto, 1992; Takada \& Kotani, 1992). The lipid As, like the LPS, produce a variety of immunobiological effects in animals and humans (Takada \& Kotani, 1992). 


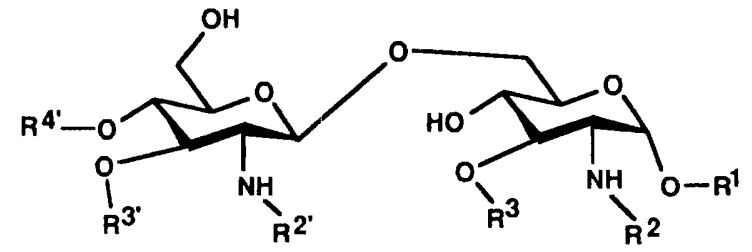

\begin{tabular}{|lcccccc|}
\hline & $\mathbf{R}^{4^{\prime}}$ & $\mathbf{R}^{3^{\prime}}$ & $\mathbf{R}^{2^{\prime}}$ & $\mathbf{R}^{3}$ & \multicolumn{1}{c}{$\mathbf{R}^{2}$} & $\mathbf{R}^{1}$ \\
\hline P. gingivalis 381 lipid A & $\mathrm{H}$ & $\mathrm{H}$ & iso- $\mathrm{C}_{17}-\mathrm{O}-\left(\mathrm{C}_{16}\right)$ & $\mathrm{H}$ & iso- $\mathrm{C}_{17}-\mathrm{OH}$ & $\mathrm{P}$ \\
Compound 506 & $\mathrm{P}$ & $\mathrm{C}_{14}-\mathrm{O}-\left(\mathrm{C}_{14}\right)$ & $\mathrm{C}_{14}-\mathrm{O}-\left(\mathrm{C}_{12}\right)$ & $\mathrm{C}_{14}-\mathrm{OH}$ & $\mathrm{C}_{14}-\mathrm{OH}$ & $\mathrm{P}$ \\
Compound 516 & $\mathrm{P}$ & $\mathrm{C}_{14}-\mathrm{O}-\left(\mathrm{C}_{14}\right)$ & $\mathrm{C}_{14}-\mathrm{O}-\left(\mathrm{C}_{12}\right)$ & $\mathrm{C}_{14}-\mathrm{OH}$ & $\mathrm{C}_{14}-\mathrm{O}-\left(\mathrm{C}_{16}\right)$ & $\mathrm{P}$ \\
\hline
\end{tabular}

Fig. 1. Chemical structure of $P$. gingivalis lipid $A$, and of synthetic $E$. coli-type and Salmonella-type lipid $A$ compounds 506 and 516. Abbreviations: $\mathrm{P}, \mathrm{PO}(\mathrm{OH})_{2} ; \mathrm{C}_{14}-\mathrm{OH},(R)$-3-hydroxytetradecanoyl; $\mathrm{C}_{14}-\mathrm{O}-\left(\mathrm{C}_{12}\right)$, $(R)$-3-dodecanoyloxytetradecanoyl; $\mathrm{C}_{14}-\mathrm{O}-\left(\mathrm{C}_{14}\right),(R)$-3-tetradecanoyloxytetradecanoyl; $\mathrm{C}_{14}-\mathrm{O}-\left(\mathrm{C}_{16}\right),(R)$-3-hexadecanoyloxytetradecanoyl; iso- $\mathrm{C}_{17}-\mathrm{OH}, 3-\mathrm{hydroxy}$ 15-methylhexadecanoyl; iso- $C_{17}-O-\left(C_{16}\right)$, 3-hexadecanoyloxy-15-methylhexadecanoyl.

Porpbyromonas (Bacteroides) gingivalis, a black-pigmented anaerobic rod, is suspected to be a periodontopathic organism (Duerden et al., 1987; Mayrand \& Holt, 1988; Slots \& Listgarten, 1988). This organism possesses various cell surface components such as LPS, capsules, fimbriae and outer-membrane proteins, and extracellular vesicles (Mayrand \& Holt, 1988; Holt \& Bramanti, 1991; Ogawa et al., 1991). P. gingivalis LPS have different chemicobiological properties from the classical enterobacterial LPS (Hamada et al., 1990). The endotoxic ability of LPS from $P$. gingivalis is very low as compared with enterobacterial preparations (Joiner et al., 1982; Nair et al., 1983; Lindberg et al., 1990; Ogawa, 1994).

Ogawa (1993) purified lipid A from P. gingivalis strain 381 and characterized its chemical structure, showing it to consist of $\beta$ - $(1 \rightarrow 6)$-linked glucosamine disaccharide 1 monophosphate with one hydroxyacyl group and one acyloxyacyl group, i.e. 3-hydroxy-15-methylhexadecanoyl and 3-hexadecanoyloxy-15-methylhexadecanoyl groups at the 2 - and 2 -positions, respectively. $P$. gingivalis lipid A exhibited no or very low endotoxic activities and beneficial immunobiological effects (Ogawa, 1994).

In the present study, we examined the cytokine-inducing activities of $P$. gingivalis lipid $A$ in human peripheral blood monocyte/macrophage or mononuclear cell culture and studied its immunopharmacological effects such as antagonistic, antitumour, natural killer and antiviral activities. The unique and different structure-function relationships of $P$. gingivalis lipid $A$ and its LPS as compared with those of synthetic $E$. coli-type and Salmonella type lipid A (compounds 506 and 516) are discussed.

\section{METHODS}

Bacteria and preparation of LPS. $P$. gingivalis strain 381 was grown anaerobically in GAM broth (Nissui, Tokyo), supplemented with haemin and menadione, at $37^{\circ} \mathrm{C}$ for $26 \mathrm{~h}$. Bacterial cells were collected by centrifugation, washed three times with pyrogen-free water and lyophilized. LPS were extracted from lyophilized cells by the hot phenol/water method (Westphal \& Jann, 1965), and the crude extract was purified by repeated ultracentrifugation $(100000 \mathrm{~g}, 3 \mathrm{~h})$ followed by treat- ment with nuclease $P_{1}$ (Yamasa Shoyu, Choshi) and finally lyophilized (Ogawa, 1993).

Preparation and purification of lipid A. Purified LPS (100 mg) were hydrolysed in $0.6 \%(\mathrm{v} / \mathrm{v})$ acetic acid at $105^{\circ} \mathrm{C}$ for $2.5 \mathrm{~h}$, cooled and neutralized. The hydrolysate was made up to $100 \mathrm{ml}$ with $\mathrm{H}_{2} \mathrm{O}$ and added to $200 \mathrm{ml} \quad \mathrm{CHCl}_{3} / \mathrm{MeOH} / \mathrm{H}_{2} \mathrm{O} /$ triethylamine $(30: 12: 2: 0 \cdot 1$, by vol.). The lower phase was evaporated under reduced pressure. Subsequently, the lipid A fractions $(30.5 \mathrm{mg})$ were separated by silica gel column chromatography (Silica Gel 60, 230-400 mesh; Nacalai Tesque, Kyoto) with $\mathrm{CHCl}_{3} / \mathrm{MeOH} / \mathrm{H}_{2} \mathrm{O} /$ triethylamine $(30: 12: 1 \cdot 5: 0 \cdot 1$, by vol.). The eluates were monitored by thin-layer chromatography on silica gel 60 plates. The plates were developed with $\mathrm{CHCl}_{3} / \mathrm{MeOH} / \mathrm{H}_{2} /$ triethylamine $(30: 12: 2: 0 \cdot 1$, by vol.) and visualized by sulfuric acid, Dittmer-Lester reagent (Dittmer \& Lester, 1964) and triphenyltetrazolium chloride (TTC) reagent (Fischer \& Dörfel, 1954). A slow-moving compound $\left(\mathrm{R}_{F} 0 \cdot 3\right)$ was detected as a single spot as the major component (Ogawa, 1993). The chemical structure of lipid A from LPS of $P$. ginginalis strain 381 (Fig. 1). was characterized by conventional chemical procedures, gas-liquid chromatography, nuclear magnetic resonance spectroscopy and mass spectrometry (Ogawa, 1993).

Reference natural and synthetic products. E. coli O55: B5 LPS were obtained from List. E. coli- and Salmonella-type synthetic lipid A (compounds 506 and 516) were purchased from Daiichi Pure Chemicals; their chemical structures are indicated in Fig. 1 (Kusumoto, 1992). Both bacterial and synthetic products were dissolved at a concentration of $2 \mathrm{mg} \mathrm{ml}^{-1}$ in $0.1 \%(\mathrm{v} / \mathrm{v})$ triethylamine aqueous solution. The stock solution was kept at $4{ }^{\circ} \mathrm{C}$ and appropriately diluted with pyrogen-free phosphate buffered saline (PBS; Biken), or cell culture medium before use for assay.

Preparation of culture supernatants. Heparinized venous blood drawn from healthy donors was fractionated by using Histopaque (Sigma) to obtain peripheral blood mononuclear cells (PBMC) in which monocytes were enriched (Böyum, 1968). PBMC were washed with PBS and suspended at $1.5 \times 10^{6}$ cells $\mathrm{ml}^{-1}$ in RPMI 1640 medium (Biken) supplemented with $10 \%(\mathrm{v} / \mathrm{v})$ foetal bovine serum (FBS, HyClone). In addition, PBMC $\left(1.5 \times 10^{5}\right.$ per well) were incubated at $37^{\circ} \mathrm{C}$ for $2 \mathrm{~h}$ in humidified air containing $5 \%(\mathrm{v} / \mathrm{v}) \mathrm{CO}_{2}$ in a 96 -well culture plate (Becton Dickinson) followed by removal of nonadherent cells to perform monocyte/macrophage culture.

The indicated concentrations of test specimens were added to PBMC for interferon- $\gamma$ (IFN- $\gamma$ ) assay or to monocytes/ macrophages for other cytokine assays as described below; the 
cells were incubated at $37{ }^{\circ} \mathrm{C}$ in air containing $5 \%(\mathrm{v} / \mathrm{v}) \mathrm{CO}_{2}$, for $72 \mathrm{~h}$ in $\mathrm{PBMC}$ culture or for $24 \mathrm{~h}$ in monocyte/macrophage culture.

In some cxperiments the antagonistic effects of $P$. gingivalis LPS and its lipid A against E. coli LPS- or compound 506-induced interleukin-1 $\beta$ (IL-1 $\beta$ ) production were examined as follows. Monocytes/macrophages were cultured at $37^{\circ} \mathrm{C}$ for $24 \mathrm{~h}$ in RPMI 1640 medium containing $10 \%(\mathrm{v} / \mathrm{v})$ FBS with $0.5 \mu \mathrm{g}$ $\mathrm{ml}^{-1}$ of $E$. coli LPS or compound 506 with or without the indicated doses of $P$. gingivalis LPS or its lipid A. After incubation, supernatants were collected and used for cytokine assays as described below.

Cytokine assay. The production and amount of the cytokines IL-1 $\beta$ (Otsuka Pharmaceuticals) IL-6, IL-8, granulocytemacrophage colony stimulating factor (GM-CSF), tumour necrosis factor- $\alpha$ (TNF- $\alpha$ ) (Amersham), IFN- $\gamma$ (Genzyme) and IL-1 receptor antagonist (IL-1 ra; R\&D) were measured in culture supernatants by means of a commercial ELISA kit system. These assays were performed according to the manufacturer's instructions, and the data were determined by standard curves prepared for each assay.

Preparation of splenic macrophages. Splenic macrophages were obtained from Balb/c mice (Japan SLC, Shizuoka) as described by Cowing et al. (1978). Briefly, spleen cells were washed twice with RPMI 1640 medium and suspended to $3 \times 10^{7}$ cells $\mathrm{ml}^{-1}$ in $0.01 \mathrm{M}$ potassium-bicarbonate-buffered ammonium chloride $(0.155 \mathrm{M}, \mathrm{pH} 7 \cdot 2)$ containing $2 \%(\mathrm{v} / \mathrm{v})$ FBS at $4{ }^{\circ} \mathrm{C}$, to lyse erythrocytes. The cells were washed twice with RPMI 1640 supplemented with $10 \%$ (v/v) FBS and $5 \mathrm{ml}$ aliquots of this suspension $\left(1 \times 10^{7}\right.$ cells $\left.\mathrm{ml}^{-1}\right)$ were added to $100 \mathrm{~mm}$ plastic Petri dishes. The cells were incubated at $37^{\circ} \mathrm{C}$ for $2 \mathrm{~h}$ to permit adherence, and then the dishes were washed with warm RPMI 1640 medium and reincubated for $18 \mathrm{~h}$. After incubation, the dishes were washed three times with warm medium, and treated with $5 \mathrm{ml} 0.6 \mathrm{mM}$ EDTA (Wako) at $37^{\circ} \mathrm{C}$ for $20 \mathrm{~min}$. The adherent cells were removed from the plates, washed and resuspended to $2 \times 10^{6}$ cells $\mathrm{ml}^{-1}$ in RPMI 1640 medium.

Cytostatic assay. Cytostasis of Meth A (methyl-cholanthreneinduced fibrosarcoma from a Balb/c mouse) as a target cell was assessed by a tritium-labelled thymidine $\left(\left[{ }^{3} \mathrm{H}\right] \mathrm{dThd}\right)$ uptake inhibition assay described by Krahenbuhl et al. (1976). Briefly, splenic macrophages as described above were suspended at $2 \times 10^{6}$ cells $\mathrm{ml}^{-1}$ in RPMI 1640 medium containing $10 \%(\mathrm{v} / \mathrm{v})$ FBS, and a $0 \cdot 1 \mathrm{ml}$ aliquot of the cell suspension was added to each well containing Meth $\mathrm{A}\left(2 \times 10^{4}\right.$ cells in $\left.0 \cdot 1 \mathrm{ml}\right)$ together with, or without, test specimens at the indicated concentrations. After incubation for $18 \mathrm{~h}$ at $37^{\circ} \mathrm{C}$ in a humidified atmosphere of air containing $5 \%(\mathrm{v} / \mathrm{v}) \mathrm{CO}_{2}$, groups of wells were pulsed with $\left[{ }^{3} \mathrm{H}\right.$ ]d Thd $\left(37 \mathrm{kBq}\right.$ in $0.01 \mathrm{ml}$, specific activity $74 \mathrm{GBq} \mathrm{mmol}^{-1}$; ICN Biomedicals) and further incubated for $6 \mathrm{~h}$; target cells were then harvested on glass filter paper. $\left[{ }^{3} \mathrm{H}\right] \mathrm{d}$ Thd uptake was measured by liquid scintillation counting (LKB-Wallac RackBeta 1215). The cytostatic activity of the macrophages was calculated as follows: cytostatic activity $(\%)=100 \times[$ (c.p.m. in cultures containing macrophages alone) - (c.p.m. in cultures containing macrophages with test specimen)]/(c.p.m. in cultures containing macrophages alone).

Cytotoxicity assay. Cytolysis was measured as the release of ${ }^{51} \mathrm{Cr}$-labelled Meth A, which was used as a target cell (Taffet \& Russell, 1981). Briefly, target cells in the exponential growth phase were incubated for $1 \mathrm{~h}$ in RPMI 1640 medium supplemented with ${ }^{51} \mathrm{Cr}$-labelled sodium chromate $\left(3.7 \mathrm{MBq} \mathrm{ml}^{-1}\right.$; specific activity $10.5 \mathrm{GBq} \mathrm{mg}^{-1}$; Radiomedicals). The cells were then washed three times with RPMI 1640 medium to remove unbound radiolabel and resuspended in the same medium containing $10 \%(\mathrm{v} / \mathrm{v})$ FBS at a concentration of $2 \times 10^{5}$ cells $\mathrm{ml}^{-1}$. A $0 \cdot 1 \mathrm{ml}$ aliquot of cell suspension was added to each well containing splenic macrophages $\left(2 \times 10^{5}\right.$ cells in $\left.0 \cdot 1 \mathrm{ml}\right)$ as described above with or without test specimens, and incubated for $18 \mathrm{~h}$ at $37^{\circ} \mathrm{C}$ in a humidified atmosphere of air containing $5 \%(\mathrm{v} / \mathrm{v}) \mathrm{CO}_{2}$. After incubation, the supernatant was removed from each well and the radioactivity was measured with a gamma-counter (LKB-Wallac Compu Gamma 1282). Cytotoxicity was calculated as follows: cytolytic activity $(\%)=$ $100 \times($ experimental release - spontaneous release) $/$ (total release-spontaneous release), in which spontaneous release was the amount of ${ }^{51} \mathrm{Cr}$ released by target cells alone and total release was the amount of ${ }^{51} \mathrm{Cr}$ released by target cells which had been lysed with $0 \cdot 1 \mathrm{M} \mathrm{NaOH}$.

Natural killer (NK) cell assay. NK cell activity was determined by a radioactive release assay (Brunner et al., 1968). Balb/c mice were injected intravenously with the indicated doses of test specimens on days 0 and 7 . The spleen cells $\left(1 \times 10^{6}\right.$ in $\left.0 \cdot 1 \mathrm{ml}\right)$ obtained from Balb/c mice $7 \mathrm{~d}$ after the final injection were then incubated with ${ }^{51} \mathrm{Cr}$-labelled Y AC-1 lymphoma cell line $\left(2 \times 10^{4}\right.$ cells in $0 \cdot 1 \mathrm{ml}$ ), which is a moloney-virus-induced lymphoma of $\mathrm{A} / \mathrm{Sn}$ origin, in an effector/target cell ratio of $50: 1$ for $4 \mathrm{~h}$ at $37{ }^{\circ} \mathrm{C}$ in a humidified atmosphere of air containing $5 \%(\mathrm{v} / \mathrm{v})$ $\mathrm{CO}_{2}$. After incubation, $0 \cdot 1 \mathrm{ml}$ supernatant was collected from each well and the radioactivity was counted with a gammacounter. Cytotoxicity was calculated as follows: NK cell activity $(\%)=100 \times($ experimental release - spontaneous release $) /$ (total release-spontaneous release), in which experimental release was the mean c.p.m. released by target cells together with effector cells; spontaneous release was the mean c.p.m. released by target cells alone; and total release was the total amount of ${ }^{51} \mathrm{Cr}$ incorporated into target cells which had been lysed with $0 \cdot 1 \mathrm{M} \mathrm{NaOH}$.

Antiviral activity against vesicular stomatitis virus. Antiviral activity was assessed by inhibition of the cytopathogenic effect of vesicular stomatitis virus, as an interferon-sensitive challenge virus (Armstrong, 1981). Briefly, murine fibroblastic L929 cells $\left(4 \times 10^{4}\right.$ in $\left.0.1 \mathrm{ml}\right)$ were incubated with or without $0.1 \mathrm{ml}$ of serial two-fold dilutions of each test specimen (maximum concentration $1 \mathrm{mg} \mathrm{ml}^{-1}$ ) for $24 \mathrm{~h}$ at $37^{\circ} \mathrm{C}$ in a humidified atmosphere of air containing $5 \%(\mathrm{v} / \mathrm{v}) \mathrm{CO}_{2}$. After removal of culture supernatant the cultures were exposed to vesicular stomatitis virus $\left(100\right.$ TCID $_{50}$ in $\left.0.1 \mathrm{ml}\right)$ and incubated for $24 \mathrm{~h}$ at $37{ }^{\circ} \mathrm{C}$; the $\mathrm{L} 929$ cells were then fixed in $5 \%(\mathrm{v} / \mathrm{v})$ formaldehyde (Wako) followed by staining with $0.5 \%(\mathrm{w} / \mathrm{v})$ crystal violet (Wako). After washing, the plates were dried in air. Since viable cells retained the dye, the $A_{595}$ of each well was read with a Titertek Multiskan MC photometer (Flow). Values obtained from triplicate cells were averaged to obtain the mean value. The $50 \%$ effective dose $\left(\mathrm{ED}_{50}\right)$ was calculated for each test sample by the method of Kärber (1931).

Statistics. Each assay was done in triplicate, and the means and standard errors were calculated. Comparisons between the test and control groups were done by Student's $t$-test for independent samples.

\section{RESULTS}

\section{Induction of cytokine production}

Table 1 summarizes the results of cytokine assays performed with P. gingivalis lipid A and its LPS as compared with E. coli LPS and synthetic E. coli- and Salmonella-type lipid A (compounds 506 and 516). P. gingivalis LPS and its lipid A induced considerably weaker IL- $1 \beta$ and TNF- $\alpha$ 
Table 1. Comparison of the production of various cytokines in human peripheral blood monocyte/macrophage or mononuclear cell culture induced by $P$. gingivalis LPS and its lipid A as compared with $E$. coli LPS and synthetic compounds

Cytokines produced were determined by an ELISA kit system. Test specimens were added to human peripheral blood mononuclear cell culture for IFN- $\gamma$ assay and to human peripheral blood monocyte/macrophage culture for other cytokine assays. The data are expressed as means \pm SE of three different cultures. ND, Not done.

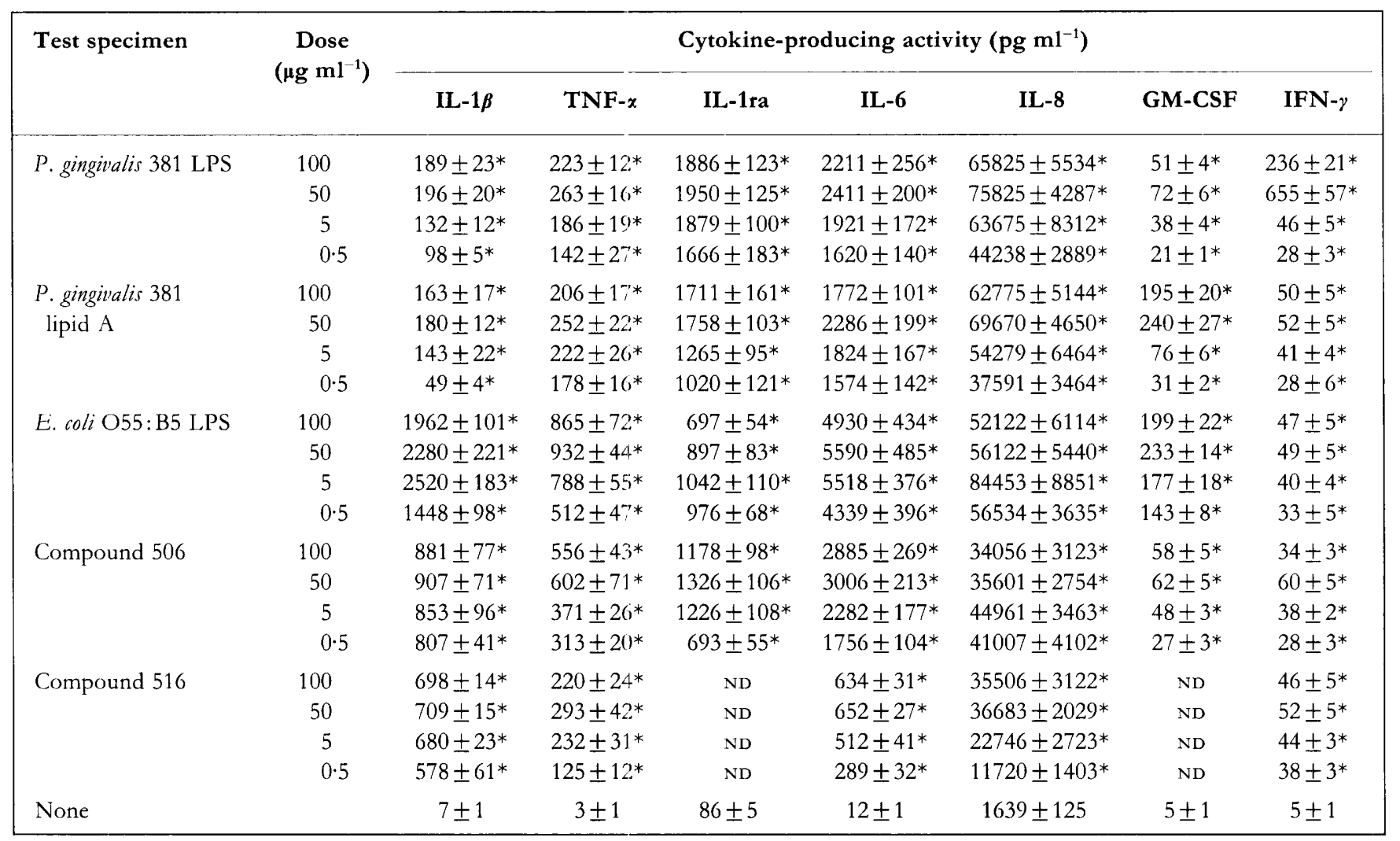

* Statistically significant difference from the value in control cultures at $P \leqslant 0 \cdot 01$.

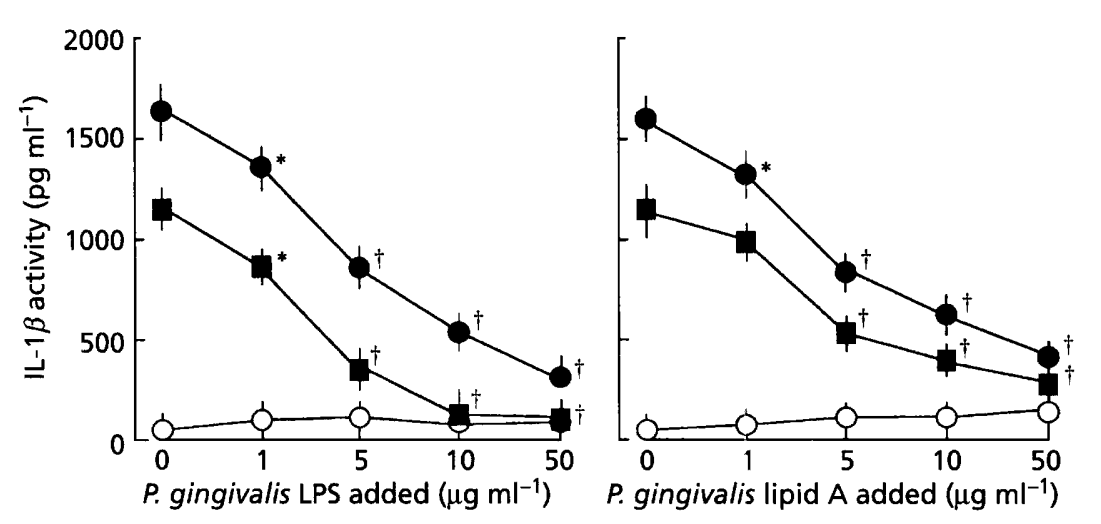

Fig. 2. Antagonistic effects of $P$. gingivalis LPS and its lipid A against production of IL$1 \beta$ induced by $E$. coli LPS or its synthetic lipid A compound 506. Human peripheral blood monocytes/macrophages were cultured at $37^{\circ} \mathrm{C}$ for $24 \mathrm{~h}$ in RPMI 1640 medium containing $10 \%(\mathrm{v} / \mathrm{v})$ FBS with $0.5 \mu \mathrm{g} \mathrm{ml}^{-1}$ of $E$. coli LPS (O) or compound $506(\square)$, with or without the indicated doses of $P$. gingivalis LPS or its lipid A (O). After incubation, the supernatants were collected, and the production and amount of $\mathrm{IL}-1 \beta$ were measured by using an ELISA kit system. Experiments were done at least three times, and representative results are presented. Each assay was done in triplicate, and the data were expressed as means $\pm \mathrm{SE}$. The difference between the groups with and without the test specimens added was significant by Student's $t$-test $(* P \leqslant 0.05$ or $+P \leqslant 0.01)$.

production than did E. coli LPS and compounds 506 and 516 in human peripheral blood monocyte/macrophage cultures. In contrast, $P$. gingivalis LPS and its lipid A induced higher IL-1 ra production than did E. coli LPS and compound 506. Furthermore, P.gingivalis lipid $A$ and its LPS stimulated human monocytes/macrophages, re- 


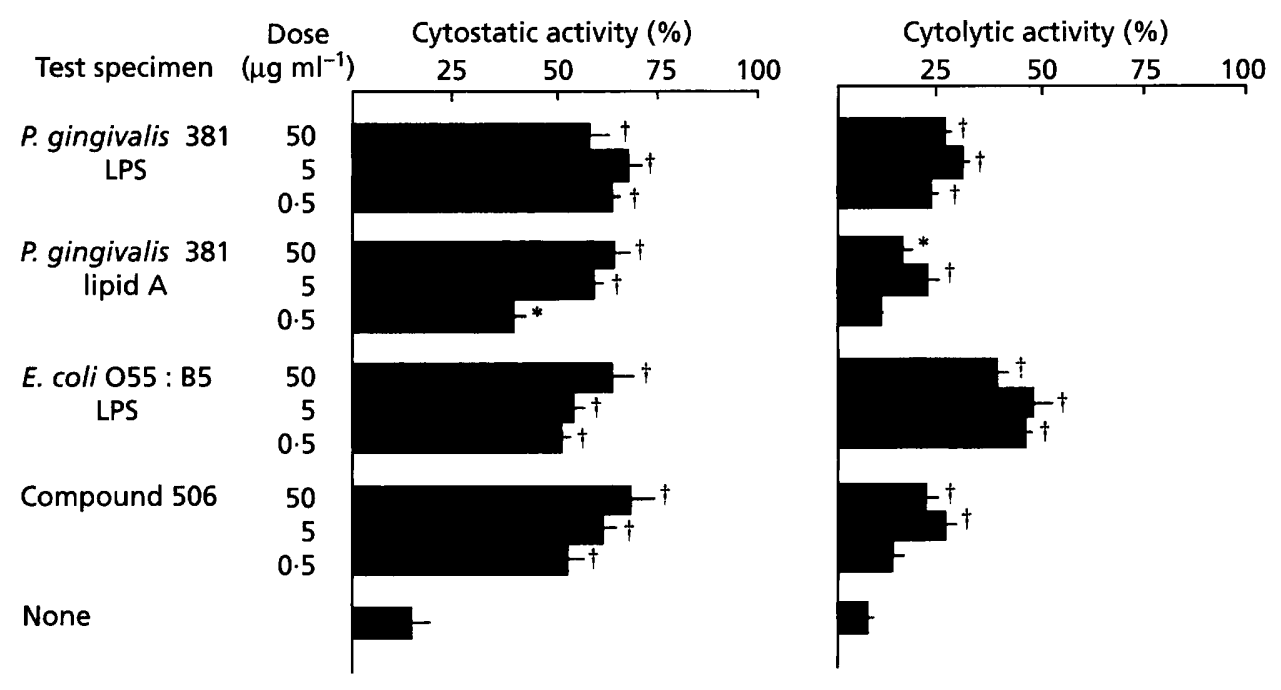

Fig. 3. Antitumour activities of $P$. gingivalis LPS and its lipid A. Cytostasis of Meth $A$ as a target cell was assessed by a $\left[{ }^{3} \mathrm{H}\right] \mathrm{dTh}$ T uptake inhibition assay (see Methods for details). The cytostatic activity was determined as the degree of inhibition of $\left[{ }^{3} \mathrm{H}\right] \mathrm{dThd}$ uptake in the target cells and the data are expressed as means $\pm \mathrm{SE}$ of three different cultures. Cytolytic activity was measured as release of ${ }^{51} \mathrm{Cr}$-labelled Meth A (see Methods). The data are expressed as means \pm SE of three different cultures. The difference between the test samples and the negative control was significant by Student's $t$ test $(* P \leqslant 0.05$ or $+P \leqslant 0.01)$.

leasing very high levels of IL-6 and IL-8 into the culture supernatants in a dose-dependent manner. P. gingivalis lipid A and E. coli LPS also elicited GM-CSF production in cell culture supernatants when stimulated. IFN- $\gamma$ production was considerably more strongly induced by $P$. gingivalis LPS than by the other test specimens (Table 1).

Antagonistic effects of $P$. gingivalis LPS and its lipid A against IL- $1 \beta$ production induced by $E$. coli LPS or compound 506 were assessed in human monocyte/ macrophage cultures. As shown in Fig. 2, the addition of $P$. gingivalis lipid A or its LPS significantly inhibited IL- $1 \beta$ production induced by $E$. coli LPS or compound 506 in a dose-dependent manner, with IL-1 $\beta$ production being almost completely inhibited at a dosage of $50 \mu \mathrm{g} \mathrm{ml} \mathrm{m}^{-1}$ of either $P$. gingivalis LPS or its lipid A.

\section{Immunopharmacological activities}

Antitumour activities of activated splenic macrophages of mice. Cytostasis and cytolysis of Meth A fibrosarcoma as a target cell by splenic macrophages of Balb/c mice activated by $P$. gingivalis LPS or its lipid A were assessed. As shown in Fig. 3, the proliferation of Meth A was significantly inhibited in a dose-dependent manner when target cells were cultured with splenic macrophages in the presence of the indicated doses of $P$. gingivalis LPS or its lipid A. P. gingivalis lipid A and its LPS reduced the proliferation of Meth A more effectively than E. coli LPS and compound 506 . In the cytolytic assay, $P$. gingivalis LPS and its lipid A exhibited tumoricidal activities at concentrations ranging from 0.5 to $50 \mu \mathrm{g}$ $\mathrm{ml}^{-1}$. P. gingivalis lipid A and compound 506 had weaker cytolytic activity than their respective parent LPS (Fig. 3).

NK cell activity. NK cell activities of $P$. gingivalis LPS and

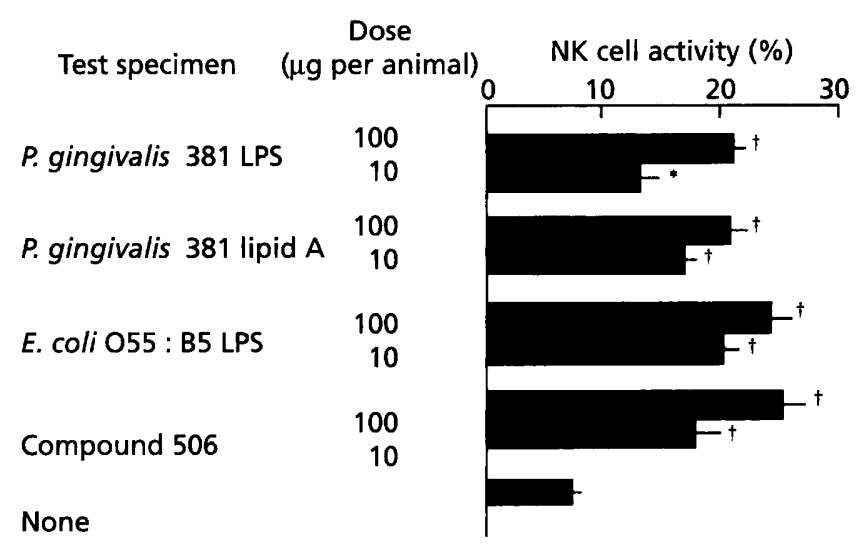

Fig. 4. NK cell activity of $P$. gingivalis LPS and its lipid $A$, determined by a ${ }^{51} \mathrm{Cr}$ release assay (see Methods). The data are expressed as means \pm SE of three different cultures. The difference between the test samples and the negative control was significant by Student's $t$-test $\left({ }^{\star} P \leqslant 0.05\right.$ or $\left.+P \leqslant 0.01\right)$.

its lipid A were tested against YAC-1 lymphoma cell line in spleen cells treated with these stimuli. As shown in Fig. 4 , the induction of NK cell activities was found in the spleen cells of Balb/c mice administered intravenously with the indicated doses of either $P$. gingivalis LPS or its lipid A. The NK cell activities were almost equivalent to those obtained with E. coli LPS and compound 506. The degrees of inhibitory effects were comparable to those of spleen cells obtained from Balb/c mice injected intravenously with $200 \mu \mathrm{g}$ of test specimens (data not shown).

Antiviral activity against vesicular stomatitis virus. Antiviral activities of $P$. gingivalis LPS and its lipid A were assessed by inhibition of the cytopathogenic effects of 
vesicular stomatitis virus. $P$. gingivalis lipid $A$ and its LPS exhibited clear antiviral activity at $\mathrm{ED}_{50}$ values ranging from 83.3 to $107.1 \mu \mathrm{g} \mathrm{m}^{-1}$. The antiviral effect was stronger than that of E. coli LPS or compound 506, both of which had an $\mathrm{ED}_{50}$ of $277 \cdot 8 \mu \mathrm{g} \mathrm{ml} \mathrm{g}^{-1}$.

\section{DISCUSSION}

Recently, the chemical structure of $P$. gingivalis strain 381 lipid A has been determined (Ogawa, 1993). The lipid A backbone consists of a $\beta(1 \rightarrow 6)$-linked glucosamine disaccharide which is phosphorylated at the 1 position of the reducing sugar. However, this lipid A structure lacks an ester-linked phosphate group which is bound to the hydroxy group at the $4^{\prime}$-position of the nonreducing sugar (Fig. 1). The hydroxyl groups at the 3-, 3'-, 4-, 4'and $6^{\prime}$-positions of $P$. gingivalis lipid A backbone are also free. The molecule possesses 3-hydroxy-15-methylhexadecanoic acid and 3-hexadecanoyloxy-15-methylhexadecanoic acid moieties amide-linked at the 2- and 2'positions, respectively (Fig. 1).

The present study showed that $P$. gingivalis lipid A induces very weak production of proinflammatory cytokines such as IL- $1 \beta$ and TNF- $\alpha$ in human peripheral blood monocyte culture as compared with compounds 506 and 516 (Table 1). On the other hand, higher production of the antiinflammatory cytokine, IL-1 ra, was observed in culture supernatants of human peripheral blood monocytes/ macrophages stimulated by $P$. gingivalis lipid A. Ulich $e t$ al. (1991) reported that IL-1 ra inhibits LPS-induced acute inflammation. Among the proinflammatory cytokines, $P$. gingivalis lipid A and its LPS up-regulate IL-6 and IL-8 production in human monocyte/macrophage culture, whereas these molecules down-regulate IL- $1 \beta$ and TNF- $\alpha$ production (Table 1). Our results show that $P$. gingivalis lipid A possesses clear immunopharmacological effects such as antagonistic, antitumour, NK cell and antiviral activities. $P$. gingivalis lipid A exhibits stronger immunobiological effects - such as mitogenic responses in $\mathrm{C} 3 \mathrm{H} /$ $\mathrm{HeJ}$ and $\mathrm{C} 3 \mathrm{H} / \mathrm{HeN}$ mouse spleen cell cultures, polyclonal $\mathrm{B}$-cell activation of $\mathrm{Balb} / \mathrm{c}$ mouse spleen cells, and immunoadjuvant effects - as compared with compound 506 (Ogawa, 1994). The up- or down-regulation of cytokine production may influence not only its nontoxicity but also the strong beneficial effects of $P$. gingivalis lipid A.

Flad et al. (1993) reported that maximal production of cytokines such as IL-1, IL-6 and TNF from human peripheral mononuclear cells may be associated with the bisphosphorylated and hexa-acylated lipid A (compound 506) corresponding to E. coli-type lipid A, while hepta-, penta-, tetra- or biacyl lipid $\mathrm{A}$ is less active. In the present study $P$. gingivalis-type triacylated lipid A induced lower levels of IL- $1 \beta$ and TNF- $\alpha$ production than did compounds 506 (hexa-acylated) and 516 (hepta-acylated) (Table 1). However, higher or comparable production of other cytokines such as IL-1 ra, IL-6, IL-8, GM-CSF and IFN- $\gamma$ by $P$. gingivalis lipid A was seen as compared with compound(s) 506 and/or 516. It is generally considered that an increased number of 3-acyloxyacyl groups is related to a reduction in the bioactivity of the disaccharide molecule (Takada \& Kotani, 1992). Salmonella- and Proteus mirabilis-type lipid A were less active than E. coli-type lipid A in most bioassays (Kotani et al., 1986; Shimizu et al., 1987). Aschauer et al. (1990) also reported that the disaccharide 1-phosphate, acylated at positions $2,2^{\prime}, 3$, but not the corresponding isomer $2,3,2^{\prime}$, was a potent inducer of TNF release. P. gingivalis lipid A, having only one 3-acyloxyacyl group, exerted strong immunobiological activities. The different chemical structure due to phosphorylation and acylation patterns of hexosamine disaccharide may be a key factor in the up- or downregulation by lipid $\mathrm{A}$ of the various cytokine-producing activities of immunocytes. The existence of a suitable balance between agonistic and antagonistic effects of $P$. gingivalis lipid $\mathrm{A}$ in the induction of cytokines, followed by a complex regulation of the cytokine network, may result in the diminution of endotoxic activities, while eliciting definite immunopharmacological effects.

$P$. gingivalis LPS and its lipid A inhibit E. coli LPS- or compound 506-induced IL- $1 \beta$ production in human peripheral blood monocytes/macrophages (Fig. 2). It was previously reported that non-toxic LPS derived from Bacteroides fragilis, Rbodobacter capsulatus and Rhodopseudomonas sphaeroides inhibited LPS-induced proinflammatory cytokine (Loppnow et al., 1990; Kirkland et al., 1991; Kirikae et al., 1991). Flad et al. (1993) reported that tetra-acylated synthetic compound of E. coli precursor $\mathrm{Ia}\left(\mathrm{VI}_{\mathrm{A}}\right)$ (compound 406) and its $\alpha$-oxyethyl analogue PE4, but not a monosaccharide lipid A precursor, lipid X, inhibited LPS-induced IL- $1 \beta$, TNF and IL-6-production by human mononuclear cells or monocytes. $P$. gingivalis lipid A exhibits no or very low endotoxic activities such as lethal toxicity in galactosamine-loaded mice, preparative ability for local Shwartzman reaction, pyrogenicity, and activity in the Limulus test (Ogawa, 1994). This can be explained by the fact that $P$. gingivalis lipid A possesses antagonistic effects for LPS- or lipid A-induced IL- $1 \beta$ production, and not only weak IL- $1 \beta$ - but also high IL1 ra-inducing activities.

The defence mechanisms against bacterial infection or tumour cells induced by LPS are mainly macrophage activation (Cohn, 1962; Adams \& Nathan, 1983). P. gingivalis LPS and its lipid A exhibit clear macrophage activation activities such as antitumour activities and NK cell activity in Balb/c mice (Figs 3 and 4). GM-CSF and IFN- $\gamma$ have been regarded as important factors in host defence mechanisms, and are well known to be associated with activation of macrophages and NK cells (Vogel \& Hogan, 1990). P. gingivalis lipid A can also induce higher or comparable production of GM-CSF and IFN- $\gamma$ as compared with compound 506 (Table 1). P. gingivalis LPS elicited IFN $-\gamma$ production more effectively than its lipid A (Table 1), and this effect may thus be due to other component(s) within the LPS molecule. There is high interest in the induction of IFN- $\gamma$ by $P$. gingivalis LPS, so work is in progress to characterize the LPS components. It was recently reported that a synthetic compound GLA60 , which is a 4-O-phosphono-D-glucosamine derivative carrying 3-O-3-tetradecanoyl-oxytetradecanoyl and $\mathrm{N}$-3- 
hydroxytetradecanoyl groups, exhibits NK cell activity, antiviral activity against murine cytomegalovirus and phagocytic activity (Ikeda et al., 1993). Our study also demonstrated that $P$. gingivalis lipid A and its LPS exhibit a stronger antiviral activity against vesicular stomatitis virus than either E. coli LPS or compound 506. These molecules may directly affect L929 cells and/or vesicular stomatitis virus, resulting in protection of the cells against the virus, or induce the release of cytokines from L929 cells.

In conclusion, we have demonstrated that $P$. gingivalis lipid $A$ has different immunobiological activities from those of enterobacterial lipid As. P. gingivalis lipid A may be considered as a potent immunomodulator molecule for possible clinical use as a non- or low-toxic and immunobiologically active drug. Further studies are needed to investigate the immunopharmacological effects of $P$. gingiralis lipid $A$ and to obtain new compounds; we are attempting to synthesize the lipid $A$ and analogues with a better balance between beneficial and toxic activities.

\section{REFERENCES}

Adams, D. O. \& Nathan, C. F. (1983). Molecular mechanisms in tumor-cell killing by activated macrophages. Immunol Today 4, $166-171$.

Armstrong, J. A. (1981). Cytopathic effect inhibition assay for interferon: microculture plate assay. Methods Envymol 78, 381-387.

Aschauer, H., Grob, A., Hildebrandt, J., Schuetze, E. \& Stuetz, P. (1990). Highly purified lipid $X$ is devoid of immunostimulatory activity: isolation and characterization of immunostimulating contaminants in a batch of synthetic lipid X. J Biol Chem 265, 9159.9164.

Böyum, A. (1968). Isolation of mononuclear cells and granulocytes from human blood. Scand J Clin Lab Invest 21 (Suppl 97), 77-89.

Brunner, K. T., Mauel, J., Cerottini, J.-C. \& Chapuis, B. (1968). Quantitative assay of the lytic action of immune lymphoid cells on ${ }^{51} \mathrm{Cr}$-labelled allogeneic target cells in vitro; inhibition by isoantibody and by drugs. Immunology 14, 181-196.

Cohn, Z. A. (1962). The fate of bacteria within phagocytic cells. I. The degradation of isotopically labeled bacteria by polymorphonuclear leukocytes and macrophages. J Exp Med 117, 27-42.

Cowing, C., Schwartz, B. D. \& Dickler, H. B. (1978). Macrophage Ia antigens. I. Macrophage populations differ in their expression of Ia antigens. J Immunol 120, 378-384.

Dittmer, J. C. \& Lester, R. L. (1964). A simple, specific spray for the detection of phospholipids on thin-layer chromatograms. $J$ Lipid Res 5, 126-127.

Duerden, B. I., Goodwin, L. \& O'Neil, T. C. A. (1987). Identification of Bacteroides species from adult periodontal disease. J Med Microbiol 24, 133-137.

Fischer, F. G. \& Dörfel, H. (1954). Die quantitative Bestimmung reduzierender Zucker auf Papierchromatogrammen. Hoppe-Seyler's Z Physiol Chem 297, 164-178.

Flad, H.-D., Loppnow, H., Rietschel, E. T. \& Ulmer, A. J. (1993). Agonists and antagonists for lipopolysaccharide-induced cytokines. Immunobiology 187, 303-316.

Hamada, S., Takada, H., Ogawa, T., Fujiwara, T. \& Mihara, J. (1990). Lipopolysaccharides of oral anaerobes associated with chronic inflammation: chemical and immunomodulating propertics. Int Rev Immunol 6, 247-261.
Holt, S. C. \& Bramanti, T. E. (1991). Factors in virulence expression and their role in periodontal disease pathogenesis. Crit Rev Oral Biol Med 2, 177-281.

Ikeda, S., Neyts, J., Matsuura, M., Kiso, M., Hasegawa, A., Nishimura, C. \& De Clercq, E. (1993). Protective activity of lipid A analogue GLA-60 against murine cytomegalovirus infection in mice. J Med Virol 40, 222227.

Joiner, K. A., McAdam, K. P. W. J. \& Kasper, D. L. (1982). Lipopolysaccharides from Bacteroides fragilis are mitogenic for spleen cells from endotoxin responder and nonresponder mice. Infect Immun 36, 1139-1145.

Kärber, G. (1931). Beitrag zur kollektiven Behundlung pharmakologischer Reihenversuche. Naunyn-Schmiedeberg's Arch Exp Pathol Pharmakol 162, 480-483.

Kirikae, T., Kirikae, F., Schade, F. U., Yoshida, M., Kondo, S., Hisatsune, K., Nishikawa, S. \& Rietschel, E. T. (1991). Detection of lipopolysaccharide-binding proteins on membranes of murine lymphocyte and macrophage-like cell lines. FEMS Microbiol Immunol 76, 327-336.

Kirkland, T. N., Qureshi, N. \& Takayama, K. (1991). Diphosphoryl lipid A derived from lipopolysaccharide (I.PS) of Rbodopseudomonas sphaeroides inhibits activation of $70 Z / 3$ cells by LPS. Infect Immun $\mathbf{5 9}$, 1.31-1.36.

Kotani, S., Takada, H., Takahashi, I., Tsujimoto, M., Ogawa, T., Ikeda, T., Harada, K., Okamura, H., Tamura, T., Tanaka, S., Shiba, T., Kusumoto, S., Imoto, M., Yoshimura, H. \& Kasai, N. (1986). Low endotoxic activities of synthetic Salmonella-type lipid A with an additional acyloxyacyl group on the 2 -amino group of $\beta(1$ 6) glucosamine disaccharide $1,4^{\prime}$-bisphosphate. Infect Immun $\mathbf{5 2}$, 872-884.

Krahenbuhl, J. L., Lambert, L. H., Jr \& Remington, J. S. (1976). The effects of activated macrophages on tumor target cells : escape from cytostasis. Cell Immunol 25, 279-293.

Kusumoto, S. (1992). Chemical synthesis of lipid A. In Bacterial Endotoxic Lipopolysaccharides, vol. I, Molecular Biochemistry and Cellular Biology, pp. 81-105. Edited by D. C. Morrison \& J. L. Ryan. New York: CRC Press.

Lindberg, A. A., Weintraub, A., Zähringer, U. \& Rietschel, E. T. (1990). Structure-activity relationships in lipopolysaccharides of Bacteroides fragilis. Rev Infect Dis 12 (Suppl 2), S133-S141.

Loppnow, H., Libby, P., Freudenberg, M., Krauss, J. H., Weckesser, J. \& Mayer, H. (1990). Cytokine induction by lipopolysaccharide (LPS) corresponds to lethal toxicity and is inhibited by nontoxic Rhodobacter capsulatus I.PS. Infect Immun 58, 3743-3750.

Mayrand, D. \& Holt, S. C. (1988). Biology of asaccharolytic blackpigmented Bacteroides species. Microbiol Rev 52, 134-152.

Morrison, D. C. \& Ryan, J. L. (1979). Bacterial endotoxins and host immune responses. Adv Immunol 28, 293-450.

Nair, B. C., Mayberry, W. R., Dziak, R., Chen, P. B., Levine, M. J. \& Hausmann, E. (1983). Biological effects of a purified lipopolysaccharide from Bacteroides gingivalis. J Periodontal Res 18, 40-49.

Ogawa, T. (1993). Chemical structure of lipid $A$ from Porpbyromonas (Bacteroides) gingivalis lipopolysaccharide. FEBS Lett 332, 197-201.

Ogawa, T. (1994). Immunobiological properties of chemically defined lipid A from lipopolysaccharide of Porpbyromonas (Bacteroides) gingivalis. Eur J Biocbem 219, 737742.

Ogawa, T., Kusumoto, Y., Uchida, H., Nagashima, S., Ogo, H. \& Hamada, S. (1991). Immunobiological activities of synthetic peptide segments of fimbrial protein from Porphyromonas gingivalis. Biochem Biopbys Res Commun 180, 13351341.

Shimizu, T., Akiyama, S., Masuzawa, T., Yanagihara, Y., Ikeda, K., Takahashi, T., Kondo, H. \& Achiwa, K. (1987). Biological activities 
of chemically synthesized Proteus-type lipid A. Microbiol Immunol 31, 381-386.

Slots, J. \& Listgarten, M. A. (1988). Bacteroides gingivalis, Bacteroides intermedius and Actinobacillus actinomycetemcomitans in human perodontal diseases. J Clin Periodontol 15, 85-93.

Taffet, S. M. \& Russell, S. W. (1981). Macrophage-mediated tumor cell killing: regulation of expression of cytolytic activity by prostaglandin E. J Immunol 126, 424-427.

Takada, H. \& Kotani, S. (1992). Structure-function relationships of lipid A. In Bacterial Endotoxic Lipopolysaccharides, vol. I, Molecular Biochemistry and Cellular Biology, pp. 107-134. Edited by D. C. Morrison \& J. L. Ryan. New York: CRC Press.

Takayama, K. \& Qureshi, N. (1992). Chemical structure of lipid A. In Bacterial Endotoxic Lipopolysaccharides, vol. I, Molecular Biochemistry and Cellular Biology, pp. 43--65. Edited by D. C. Morrison \& J. L. Ryan. New York: CRC Press.
Ulich, T. R., Yin, S., Guo, K., del Castillo, J., Eisenberg, S. P. \& Thompson, R. C. (1991). The intratracheal administration of endotoxin and cytokines. III. The interleukin-1 (IL-1) receptor antagonist inhibits endotoxin- and IL-1 induced acute inflammation. Am J Pathol 138, 521-524.

Vogel, S. N. \& Hogan, M. M. (1990). Role of cytokines in endotoxin-mediated host responses. In Immunophysiology: Role of Cells and Cytokines: Immunity and Inflammation, pp. 238-258. Edited by J. J. Oppenheim \& E. Shevach. Oxford: Oxford University Press.

Westphal, O. \& Jann, K. (1965). Extraction with phenol-water and further applications of the procedure. Methods Carbobydr Chem 5, 83-91.

Received 11 October 1993; revised 20 January 1994; accepted 21 January 1994. 